\title{
INMIGRANTES SIRIOS Y LIBANESES EN TUCUMAN (ARGENTINA). EL RECLAMO DE LA ETNICIDAD.
}

\author{
Beatriz VITAR \\ CSIC (Madrid)
}

\section{RESUMEN}

Este artículo trata de la identificación única en los descendientes de inmigrantes árabes en Argentina, con especial referencia a la región Noroeste. La autora recurre a testimonios de personas entrevistadas y a su propia historia de vida para abordar algunos aspectos relacionados con la adaptación de diferentes generaciones de inmigrantes y con la experimentación de la etnicidad en los nietos de inmigrantes sirios y libaneses.

Palabras clave: América Latina, siglo XX. Inmigración. Historia oral.

\section{$\underline{\text { SUMMARY }}$}

This article deads with the second and third generations of arab inmigrants (syrian and lebanese) with regard to their ethnic identity in Argentina, specially those in the Northeast region. The author used personal testimonics through interviews and with her own life experience to touch on certain aspects on how these generations of inmigrants han adapted and how they had lived they ethnic values among their grandchildren of arabic origins.

Keywords: Latin America, xxth century. Inmigration. Oral History.

\section{INTRODUCCIÓN}

Tal vez en ningún otro estudio como en el de los movimientos migratorios resulten tan a propósito aquellas palabras de Edgard Morin que Thiery SAIGNES (1993) rescatara, a propósito de sus notas sobre egohistoria: "El autoanálisis del historiador es algo que se vuelve necesario a partir del momento en que se toma en serio la historia" ${ }^{1}$

La lectura de este trabajo de Saignes, cuyo contenido atendía sin duda a los dictados de tal sentencia, me ha sugerido la senda para trazar algunas pinceladas en lo referente a la vivencia de la etnicidad en los nietos de inmigrantes. Ello implica el desafío de un viaje hacia nuestro interior para desentrañar las profundas motivaciones que subyacen en determinadas opciones profesionales y en los diferentes centros de interés que han ido 
forjado nuestra trayectoria investigadora. Ya de por sí, el solo hecho de escribir estas páginas en primera persona, ha facilitado notablemente la práctica de un hondo ejercicio de reflexión, mediante el cual he ido delimitando las vías de acercamiento al tema de la inmigración árabe en Argentina y las razones que me llevaron a profundizarla.

Así pues, siguiendo la vía de un autoanálisis, intentaré explicar primeramente cómo nació y se consolidó mi interés por la inmigración siria y libanesa en Argentina, partiendo de dos circunstancias fundamentales: mi condición de nieta de inmigrantes sirios y mi propia experiencia migratoria, iniciada pocos años después de concluidos los estudios universitarios en la ciudad argentina de Tucumán. Es mi intención esbozar algunas cuestiones relacionadas con el problema de la identidad étnica entre los inmigrantes sirios y libaneses y sus descendientes, recurriendo a algunos testimonios recogidos entre hombres y mujeres pertenecientes a dicha colectividad en Tucumán -y ocasionalmente en Madrid- y al ejemplo de mi propia historia de vida $^{2}$, con lo que espero brindar algunos aportes para el estudio de las formas de vivencia de la etnicidad en la tercera generación de inmigrantes.

\section{EL INTERÉS POR LOS PROCESOS MIGRATORIOS}

En un momento en el que asistimos al desplazamiento de grandes contingentes humanos expulsados de su suelo nativo -al presente contamos con el desgarrante ejemplo de los albano kosovares de Servia-, que quiebran fronteras y nos ponen frente al Otro distinto y distante, el estudio de los movimientos migratorios puede resultar un buen antídoto contra las tentaciones etnocentristas y los irritantes sentimientos nacionalistas tan vigentes hoy.

En mi caso personal me fui acercando al fenómeno de la inmigración desde diferentes perspectivas: soy argentina de nacimiento y descendiente de inmigrantes, ya que mis abuelos formaron parte del grupo de sirios cristianos ortodoxos ingresados al país en las primeras décadas del siglo $\mathrm{XX}$; por lo demás, yo misma me instalé en España hace ya casi veinte años (una larga estancia interrumpida sólo por un fugaz retorno a Argentina en 1994), y es en este país donde me toca en la actualidad asistir, como española adoptiva que soy, a la afluencia masiva de refugiados e inmigrantes de diverso origen.

En lo que respecta a la inmigración de sirios y libaneses en Argentina y más específicamente en Tucumán, mi seguimiento del tema no ha sido lineal sino surcado, paradójicamente, por los altibajos inherentes a mi propia migración y por los avatares existenciales de ella derivados. En 1977, dos años después de acabar mis estudios de Profesorado en Historia en la Universidad Nacional de Tucumán, realicé un curso de posgrado referido a la inmigración en Argentina, planteándome entonces la 
posibilidad de emprender un estudio sobre los inmigrantes sirios y libaneses en la ciudad de Tucumán. Comenzaba a sensibilizarme con los temas migratorios; aunque yo no era del todo conciente entonces de los motivos subyacentes a estas inquietudes, fuera de la familiaridad con la qué podía mirar dicho proceso por razones de parentesco. Más bien experimentaba -de un modo no muy nítido- un cierto "llamado" a ocuparme de tales cuestiones, sintiendo que había llegado quizá la hora de detenerme a pensar en la gesta de los abuelos, es decir, en el éxodo de su tierra natal para asentarse en otras latitudes. Curiosamente, además, esta inquietud afloraba en una coyuntura en la que había comenzado a germinar la idea de emigrar de Argentina, donde se dejaban sentir de un manera desgarrante los efectos de la dictadura militar instaurada en 1976.

Si bien había nacido en mí cierto interés por la historia de mis abuelos, emocionalmente me sentía a mucha distancia de su experiencia migratoria; en el fondo me consideraba totalmente ajena a ese proceso. Vivía mi argentinidad como un hecho natural ${ }^{3}$, circunstancia que me impedía a su vez medir los efectos de una aculturación que yo misma podía quizá estar aún cumplimentando ${ }^{4}$. Sencillamente, encararía el tema como un objeto "distante" (valga la expresión) de estudio, al igual que ocurría con cualquier otro escogido dentro de mi quehacer investigador, que en aquel tiempo giraba en torno a la historia político institucional argentina en el período independiente. Ésto último, unido a la presión de las obligaciones docentes y al proyecto de marcharme a Europa, me obligaron a postergar la idea de una investigación que apenas había llegado a tomar cuerpo.

Una vez en España, mis primeros contactos con las huellas artísticas y otros legados de $\mathrm{Al}$ Andalus no sólo provocaron un impacto estético sino que significaron una revalorización de lo árabe que a la larga incrementaría mi interés por los grupos de este origen emigrados a Argentina. Así, la primera visión de las inscripciones en lengua árabe en los muros de la Alhambra tuvo la virtud de retrotraerme a una escritura recóndita, cuyos signos y aún la forma de volcarlos en el papel -de derecha a izquierdasolían lanzarme fulminantes señales de alteridad en tiempos de mis abuelos.

Sin embargo, la experimentación de todas esas sensaciones no acabó de cuajar en un sólido sentimiento étnico ni tampoco en un propósito firme de abordar el estudio del tema que tantas veces había rondado en mi cabeza. Poco después de presentada mi tesis doctoral en el área de Historia de América Colonial en $1988^{5}$ y también de cara a un posible retomo a Argentina ${ }^{6}$ libaneses en Tucumán., comencé la lectura de trabajos referidos a Siria, la tierra natal de mis ancestros; sin embargo, estas actividaes se vieron interrumpidas por la cancelación del viaje y la continuación de los estudios relacionados con mis fronteras coloniales. 
Por aquel tiempo -fines de los años '80-, en lo personal, atravesaba por una etapa de honda reflexión acerca de mi propia inmigración; estas meditaciones sobrevenían -he ahí una nueva paradoja- en un momento en el que la obtención de la nacionalidad española me arrancaba de la transitoriedad de aquellas renovaciones trimestrales, luego semestrales y finalmente anuales de la permanencia en el país, para instalarme en la seguridad de una nueva ciudadanía. En tales circunstancias comencé a "elaborar" mi condición de inmigrante en un país en el que llevaba residiendo un tiempo considerable, aunque en una situación de provisionalidad patente sobre todo en la cuestión de los "papeles": un pasaporte con estancias renovables cada tres meses en calidad de estudiante extranjera con anterioridad a la residencia laboral concedida por un año, inmediatamente antes de la nacionalización.

Otras razones obraron también como incentivo para ampliar la mirada con relación a mis orígenes étnicos: el crecimiento de los flujos migratorios hacia España, con una destacada presencia del grupo marroquí. La problemática de la inserción de estos migrantes de lengua árabe en el medio español me condujo, salvando, claro está, las distancias, a reflexionar sobre el fenómeno de los inmigrantes árabes en un país de habla hispana como Argentina.

Por último, fue a través de la conciencia de mi propia experiencia inmigratoria como llegué a valorar la de mis abuelos. De modo paralelo, parecía haberse consolidado en mí un cierto proceso de revalorización étnica que se había operado lentamente desde la llegada a España, tras mi residencia en Sevilla -por espacio de dos años- y mis viajes a otras provincias andaluzas. No obstante, lamenté profundamente que ese "despertar étnico" se produjese cuando ya no vivían los abuelos, que sin duda habrian constituido una fuente de información privilegiada para recobrar la memoria de un hecho tan trascendente para la saga familiar como lo fue la mudanza a América.

A mediados de 1993, acabado el alivio temporario de los festejos quintocentenarios para los americanistas en paro y como anticipo de la recesión que afectaría a España al siguiente año, las dificultades laborales me lanzaron a la búsqueda de nuevos horizontes geográficos, y también temáticos, aunque sin dejar de lado las cuestiones coloniales. Me introduje así de lleno en lecturas que me brindaron un panorama general de la emigración de sirios y libaneses a Estados Unidos y a países de Iberoamérica, especialmente a Argentina y Brasil ${ }^{7}$. Volvía a reflotar un viejo proyecto en una coyuntura especial, ya que planificaba un retorno para "tantear" terreno- a Argentina, lo que se concretó en diciembre de 1993. Cumplía así con el objetivo del retorno, idea que acompaña de por vida al emigrante y le ayuda a adaptarse a la sociedad receptora; incluso aunque concientemente no se elaboren planes concretos para el regreso, la meta del retorno parece formar parte del equipaje del que emigra ${ }^{8}$. 
El estudio de diferentes procesos migratorios y mis propias inquietudes con relación a los problemas de identidad en los grupos étnicos -tema tratados en mi tesis doctoral-, me llevaron a considerar la posibilidad de ocuparme de la adaptación del inmigrante y de la problemática de la etnicidad, para lo cual debía centrarme en la cuestión generacional. Curiosamente, las primeras indagaciones en el terreno, en Buenos Aires y Tucumán, se desarrollarían en medio de unas circunstancias especiales: el retorno -que acabó siendo provisional- a mi país de origen conllevaba la difícil empresa de la reinserción, proceso que en cierta medida representa una nueva experiencia migratoria ${ }^{9}$. El país que se ha dejado hace tiempo puede compararse con una serie de "fotos fijas": son imágenes y recuerdos que quedaron "congelados" en el tiempo. Quizá sea uno de los choques más duros que esperan al retornado.

De vuelta a España a fines de 1994, y puesta otra vez en la tarea de reinsertarme, realicé entre otras cosas un curso de enseñanza del español a inmigrantes; esta breve experiencia me permitió reconsiderar la cuestión de las migraciones, aunque por necesidades laborales debí dedicar una atención preferencial a mis investigaciones chaqueñas. A pesar de los altibajos señalados, $\mathrm{mi}$ interés por los fenómenos migratorios ha permanecido intacto, con el incentivo, además, de recibir permanentes "llamados de atención" de mi entorno más inmediato: actualmente vivo en Madrid en Lavapiés, un barrio céntrico y con una abrumadora presencia de inmigrantes de distinta procedencia; sin duda un espacio "multicolor" que representa un laboratorio de cotidiana experimentación de la alteridad. Con frecuencia se ha señalado a este rincón madrileño como el barrio multiétnico por excelencia de todo Madrid y de toda España; en alguna calle del barrio se ven locutorios telefónicos con carteles en castellano, inglés, árabe e incluso tagalo (la lengua hablada mayoritariamente en Filipinas), para atender a las exigencias de una clientela variada: marroquíes, filipinos, hindúes, africanos y gente procedente de diversos países de América del Sur.

\section{LA INMIGRACIÓN ARABE EN ARGENTINA. EL CASO DE LA REGIÓN DEL NOROESTE}

No ahondaré en este punto en los diversos aspectos que atañen al desarrollo histórico de la inmigración de sirios y libaneses y a las vicisitudes de su inserción en la sociedad receptora, para cuyo estudio contamos con diversos trabajos referidos al país en general, a Buenos Aires y otras provincias ${ }^{10}$ migración árabe en Argentina (Tesis Doctoral), Universidad Complutense de Madrid, 1991. y a la región Noroeste en particular, en la que se halla comprendido Tucumán ${ }^{11}$. Se trata, de acuerdo con los lineamientos del citado Seminario de Intrahistoria y Oralidad -en cuyo marco se concibió la idea de este artículo-, de aportar algunos testimonios de miembros de la colectividad sirio libanesa y los datos de mi 
propia experiencia para presentar algunas facetas del fenómeno de asimilación cultural entre dichos migrantes y sus descendientes, así como la experimentación de la etnicidad en la tercera generación, contrastando en algún caso esta información con la aportada por los trabajos citados acerca de la inmigración árabe.

La consulta de diversos estudios referidos a la presencia de grupos migrantes de origen árabe en diferentes partes del mundo me permitió en primer lugar medir la importancia de un fenómeno que, a decir verdad, conocía con mayores detalles en su dimensión americana ${ }^{12}$. En el caso de Argentina, la escasa -aunque valiosa- producción historiográfica en torno al tema, parecía el fiel reflejo del contexto histórico en el que se desarrolló la llegada al país de sirios y libaneses, una inmigración -especialmente la de los primeros- "no deseada". Así es que, en comparación al conjunto de estudios sobre la inmigración española e italiana en $\operatorname{Argentina}^{13}$ y en consonancia con la diferente acogida que tuvieron estos contingentes en relación a los de lengua árabe, los trabajos sobre esta última colectividad eran más escasos, debiendo destacarse la importancia del Centro de Estudios Migratorios Latinoamericanos de Buenos Aires, en la promoción de los mismos.

En líneas generales, el flujo migratorio de sirios y libaneses comenzó a operarse tardíamente en relación a grupos de otro origen, pero de modo intenso desde fines del siglo XIX hasta 1910. Durante los años de la Primera Guerra Mundial descendieron las cifras de ingresados al país para volver a reflotar con cifras más modestas en el periodo $1921-1930^{14}$; en la etapa posterior, que se extiende hasta mediados de siglo, siguieron registrảndose llegadas aunque en cantidades no significativas ${ }^{15}$.

La presencia del inmigrante árabe contrariaba las expectativas de los liberales argentinos que durante la segunda mitad del siglo XIX habían propulsado el poblamiento del país con grupos migrantes europeos, principalmente de origen nórdico -considerados como paradigmas de la civilización y el progreso-. Así, la imagen que de los inmigrantes árabes tuvo la sociedad receptora hasta los años 1930 bien puede considerarse como un legado de esos deseos frustrados de las élites argentinas; el mito del inmigrante europeo -"rubio de ojos azules", como modelo de lo racialmente correcto, valga la expresión- que vendría a insuflar prometedora sangre en las venas de un país en el que ya se había eliminado prácticamente a los grupos indígenas- aún permanecía vivo en algunos sectores que al principio de esta década asistían con recelo a la llegada de nuevos cabecitas negras a la gran metrópoli -Buenos Aires-, procedentes del Paraguay, Perú, Bolivia y Brasil ${ }^{16}$.

La sentencia de un funcionario de Migraciones argentino pronunciada en 1910 respecto de la inmigración de sirios y libaneses -designados como "turcos", pues tanto Siria como Líbano estaban entonces bajo el dominio 
del Imperio Otomano-, calificándola de "exótica"17 y poco rentable al país, obró como un estigma que marcó a los árabes inmigrados y a ius descendientes e influyó en la percepción que la sociedad argentina cuve de ellos durante largo tiempo. En lo que respecta a las provincias del noroeste argentino, esta apreciación negativa del árabe perduró con fuerza en las familias con cierto status social, compuestas por descendientes de españoles con largo arraigo en la tierra, situación que les merecía el orgullo de ser los herederos de los conquistadores; el inmigrante árabe fue por largo tiempo rechazado, siendo "aceptado" más tardíamente en función de su éxito económico y relumbre social. En La Rioja, provincia que también forma parte de la región del Noroeste argentino -y de donde es oriundo el actual presidente del país, Carlos Menem, hijo de musulmanes sirios-,' los estratos socialmente elevados veían a sirios y libaneses como "advenedizos" y por ende no dignos de formar parte de su círculo, según lo aportado por un informante ${ }^{18}$.

Otro testimonio revela la necesidad, en los descendientes de inmigrantes, de contrarrestar esa imagen deformada del colectivo árabe en la sociedad argentina, alimentada a lo largo de varias décadas con : los conceptos tan manidos del "turco bruto" o del "turco mercachifle", con costumbres ajenas: a la idiosincracia de la sociedad receptora. Una informante, profesional y nieta de inmigrantes sirios residente en Tucumán, comentaba el proyecto -en el que trabajaba con verdadero entusiasmo- de crear una asociación de jóvenes profesionales de ese origen, para demostrar "que no somos unos turcos timberos" ${ }^{19}$. Sin duda se quería demostrar con orgullo de qué manera se había logrado un ascenso económico y socio cultural entre los descendientes de aquellos "turcos" no deseados y con escaso prestigio. Como haciéndose eco de ese malestar, la Sociedad Sirio Libanesa de Tucumán había ya publicado tiempo atrás una larga lista de profesionales de origen sirio y libanés - claro está, de la segunda y tercera generación- como una muestra del aporte de los árabes a la sociedad local.

Con respecto a migrantes de otro origen, principalmente españoles e italianos -con una presencia masiva en el país-, existía, según he observado en mi familia, una valoración positiva sobre todo en lo referente a su predisposición al trabajo -rasgo que sin embargo suele acompañar a todo inmigrante, de cara a un posible retorno o sobre todo a los envíos de dinero a los que quedaron en el país de origen-, en especial en contraposición al elemento mestizo o criollo. Respecto a éstos, he podido ver claramente, en el caso de mi familia, las mismas apreciaciones negativas del conquistador español hacia el elemento autóctono; ello se deriva de la posición de superioridad en la que se insertó el inmigrante blanco en la sociedad argentina con respecto a los sectores étnicos secularmente marginados. Ahora bien, curiosamente, estos mismos comentarios despectivos acerca de la "indolencia" de los habitantes autóctonos, habían sido hechos por Juan Alsina, el citado funcionaro de Migraciones, con relación a los árabes, 
juicios que se sustentaban en el hecho de consagrarse en su mayoría al comercio, desechando los trabajos agrícolas.

Si bien existía la inmigración organizada, en el caso de mis abuelos se produjo de modo espontáneo, aunque siguiendo los mecanismos de la "cadena de llamada", utilizada en el caso de otros flujos migratorios a Argentina $^{20}$. Mi familia -tanto materna como paterna- era oriunda de la provincia siria de Hama, y al igual que un gran número de parientes próximos y lejanos-, se establecieron en zonas rurales de la provincia de Santiago del Estero, desde donde se operó una amplia movilidad hacia otras zonas del norte argentino como Tucumán, Salta y Jujuy. La importancia numérica de los inmigrantes sirios procedentes de Hama instalados en Santiago del Estero ha sido señalada por Jozami ${ }^{21}$, demostrando la fuerza congregante de la aldea, la "patria pequeña" entre los inmigrantes, que como bien sostiene esta autora coadyubó al fortalecimiento de la identidad étnica, juntamente con su religión. En Santiago del Estero, con una significativa presencia árabe, los inmigrantes de Siria y Líbano encontraron además similitudes climáticas con sus zonas de origen, facilitando su asentamiento. Esta característica, a la que siempre aludían mis familiares ante mi pregunta de cuál era la causa de tamaña concentración árabe en Santiago, era una de las escasas referencias que poseía acerca de esta inmmigración antes de abocarme a su estudio.

La llegada de mis abuelos paternos, ya casados en Siria, se habría producido hacia 1910; mi padre -nacido en Santiago del Estero en 1914era el mayor de los hermanos sobrevivientes -pues habían fallecido cinco, a los que no llegué a conocer-. Por el contrario, mi abuelo materno hizo de muy joven un primer viaje a América -hacia 1909- junto a un familiar, retornando al cabo de un tiempo a Siria, donde contrajo matrimonio con mi abuela. Una vez casado, decidió volver y establecerse en Argentina, a comienzos del decenio de 1920: cumplía así con lo que era habitual en los inmigrantes varones que habían llegado solos al país de acogida: retornar al "pago" para buscar esposa ${ }^{22}$. Esta rígida norma endogámica por lo general comienza a quebrarse en la segunda generación -como ocurrió en el caso de algunos de mis tíos por vía materna, cuyos cónyugues no pertenecen a la colectividad árabe-, aunque en el caso de mi familia paterna, mucho más adherida a la tradición, el matrimonio endogámico se mantuvo sin fisuras hasta la tercera generación.

Un aspecto importante de la inmigración procedente de Siria y Líbano fueron las diferencias religiosas, ya que en dichos países -hasta la Primera Guerra Mundial bajo el poder de los turcos-, la población maronita y ortodoxa fue objeto de discriminaciones y persecuciones por parte de los musulmanes. Estas circunstancias no me eran desconocidas, en especial por la firme defensa de sus creencias religiosas que a menudo hacían mis abuelos, dejando muy clara su condición de ortodoxos y por ende las diferencias que les separaban de los musulmanes; esa visceralidad en la 
defensa de la identidad religiosa podría deberse a que los grupos mahometanos -que emigraron preferentemente tras la implantación idel Protectorado francés en Siria y Líbano al concluir la Primera Guerrafueron los más discriminados dentro de la sociedad receptora por sus particularidades culturales y religiosas ${ }^{23}$. El hecho de que en el pueblo santiagueño de Frías, donde nació mi padre, hubiese una presencia destacada de sirios ortodoxos, según lo señalado por Jozami ${ }^{24}$, me indujo a valorar la marcada incidencia de esta circunstancia -reflejo de una férrea solidaridad del grupo inmigrante, favoreciendo su concentración en la zona- en lo que respecta a la mayor conciencia étnica de mi familia paterna y concretamente de mi padre, cuya defensa de los valores culturales árabes resultaba contrastante con el "acriollamiento" más acentuado de mi madre y su familia.

No había meditado en estos rasgos de la etnicidad paterna sino hasta hace unos años, en ocasión de preparar mi proyecto sobre la identidad étnica en los descendientes de inmigrantes sirios y libaneses. A fuerza de reflexión pude reconstruir en parte la memoria de los años en que aún vivía mi padre, buscando comportamientos que validaran la existencia de un fuerte orgullo étnico. Lo cierto es que a pesar de hallarse generalizado el uso del apelativo "turco" para designar a los inmigrantes árabes y sus descendientes, mi padre se resistía a aceptarlo, al igual que lo habían hechos sus progenitores, movidos por el horror a ser confundidos con musulmanes y el irremediable rechazo hacia los turcos, bajo cuya dependencia había estado Siria ${ }^{25}$.

La aldea y la familia extensa, la gran parentela ${ }^{26}$, fueron elementos aglutinantes y reforzadores de la identidad entre los inmigrantes árabes; la mayoría de los llegados a Argentina procedían de zonas rurales en las que tenía gran importancia la familia extensa, la parentela reunida en torno a la autoridad de un cheikh ${ }^{27}$. Esta pervivencia del sentimiento de clan pude vivirla cuando niña en el seno de mi familia, aunque más acentuadamente en la rama paterna, asistiendo a menudo a las casas de los parientes (especialmente las de los tíos abuelos), convertidas en puntos obligados de visita con nuestros padres domingo de por medio.

Las ocupaciones de los migrantes árabes fue prioritariamente el comercio ambulante, aspecto que ha sido comentado en los diversos trabajos dedicados a esta colectividad ${ }^{28}$, y que incluso fue recogido como estereotipo en las obras teatrales cómicas, que contaban con el fácil recurso de la estampa tan popular del comerciante "turco", ofreciendo la mercancía con su clásico vende barato beine, beineta ${ }^{29}$. Luego sobreviene la etapa de asentamiento, apareciendo el típico "boliche de turco", la "tienda almacén ${ }^{\text {" }}{ }^{30}$ en la que se despachaba toda clase de mercancías. Este tipo de negocio fue característico entre los migrantes sirios y tampoco estuvo ausente en el caso de mi familia; mi abuelo por vía materna, tras dedicarse a la venta de vacuno en el norte de Santiago ${ }^{31}$, estableció en la zona noreste 
de Salta una tienda similar, cuyo olor inefable -resultado de la suma de tan variada gama de productos almacenados- ha quedado grabado en mi memoria. Por lo general en la segunda generación se producía un ascenso económico y social, acompañado en muchos casos de participación en la política, y ya en la tercera generación, junto a todos estos adelantos, se ve un claro avance en el terreno cultural, con figuras destacadas en los más diversos campos ${ }^{32}$. Dentro de mi familia se observan similitudes en lo que respecta a la trayectoria ocupacional profesional a lo largo de las diferentes generaciones, al igual que en muchas familias de origen árabe: por lo general, es el miembro más joven de la segunda generación el que sigue estudios universitarios (es el "lujo" que la familia, ya asentada, se puede permitir), para convertirse en un hecho generalizado en la tercera.

Un campo inmensamente rico para el conocimiento del proceso de adaptación de los sirios y libaneses en Argentina es la cuestión lingüística. En lo que concierne a mi familia, una de las anécdotas que oí narrar desde pequeña fueron las peripecias idiomáticas vividas por mis abuelos maternos al establecerse en zonas del noreste santiagueño -señaladamente tierra adentro-, donde la comunicación con los pobladores autóctonos, que no hablaban español, se realizaba a través del quechua ${ }^{33}$. Esta circunstancia es señalada por Tasso al hablar de los inmigrantes árabes asentados en el campo santiagueño, quienes pudieron desplegar sus actividades comerciales aprendiendo rápidamente el quechua ${ }^{34}$, lengua que por cierto mi madre llegó a hablar de niña.

Los descendientes de inmigrantes sirios y libaneses, en su mayoría, no conocen la lengua árabe ${ }^{35}$. Este idioma comenzó a perder vigencia en la segunda generación, ante las urgencias del proceso de integración al medio argentino. Así, un informante, hijo de libaneses nacido en Argentina, explicaba que, aunque su madre lo intentaba siempre, él prefería que no le hablase en árabe, pues lógicamente en la escuela todos hablaban el castellano; albergaba el temor de ser diferente a los otros por la práctica de un español deficiente y convertirse en objeto de la mofa ${ }^{36}$. En cuanto a mi familia, sólo mi padre hablaba el árabe y mi madre apenas si lo "entendía", aunque esto era lo frecuente en la segunda generación; por lo demás, nuestro padre jamás nos habló en árabe, reservándose el uso de esta lengua para tratar con mi madre u otras personas, los temas "prohibidos" a los niños. Por último, en consonancia con el testimonio antes citado respecto al miedo a sentirse marginado en el ámbito de la escuela, pude percibir, durante mi experiencia colegial, que el ostentar un apellido español daba mayor "lustre" que otros -a excepción de los de origen inglés o francés-, sobre todo si era de raigambre, pues el provenir de los primeros pobladores blancos de la tierra aportaba un pedigree ${ }^{37}$ del que carecían los hijos o nietos de inmigrantes.

La lengua ha planteado también problemas de segregación, incluso ejercida por los primeros inmigrantes, más o menos integrados, con 
relación a los recién llegados. Una mujer nacida en Siria, de más de cincuenta años, había llegado hacía unos treinta -en 1964- a Argentina para contraer matrimonio en Jujuy ${ }^{38}$, aunque de aquellos sus primeros tiempos en el país no guardaba buen recuerdo, pues había experimentado el rechazo y la marginación cuando la parentela política hablaba en árabe en su presencia, a pesar de poderlo hacer en árabe ${ }^{39}$.

Un capítulo importante en el proceso inmigratorio de sirios y libaneses en Argentina lo constituye el conjunto de instituciones fundadas con fines diversos, esencialmente las asociaciones étnicas -con sus correspondientes órganos de difusión-, los templos, los hospitales y los colegios. Con respecto a los templos, un dato aportado por JOZAMI (1994), me permitió entender en gran parte la fuerza de la herencia cultural en mi padre, aunque ello no hubiese supuesto una decidida militancia religiosa ni tampoco una discriminación de lo católico: Frías, su ciudad natal, fue la sede del primer templo Ortodoxo Antioqueño de Hispanoamérica ${ }^{40}$, fundado en 1917 gracias a las contribuciones de la comunidad siria ortodoxa residente en dicha ciudad, donde eran mayoría. Otro rasgo indicador del apego a la tradición por parte de mi padre era su calidad de socio de la Sociedad Sirio Libanesa ${ }^{41}$, sitio de reunión social pero también de concertación de negocios, para los cuales -sin duda por una cuestión de pertenencia étnica- él prefería recurrir a dicho ámbito; obraría quizá también impulsado por la desconfianza que habrían albergado sus progenitores en el proceso de adaptación al país. Por lo demás, mi padre fue un ferviente seguidor de ciertos temas que interesaban al mundo árabe, como era el proyecto panarabista del presidente egipcio Nasser, creador de la RAU (República Árabe Unida), al punto de que se hallaba suscrito a una publicación que llevaba como título esta sigla.

\section{LA VIVENCIA DE LA ETNICIDAD EN LA TERCERA GENERACIÓN DE INMIGRANTES. UN PROYECTO INACABADO}

Fue en los Estados Unidos -país que de modo similar a Argentina presenta una gran base multiétnica en la conformación de la nacionalidad ${ }^{42}$ donde se abrió un amplio foro de discusión para debatir una serie de psoturas alternativas a la clásica interpretación del fenómeno inmigratorio basado en la teoría del melting $\operatorname{pot}^{43}$ (crisol de razas). Así, una serie de autores han señalado en aquel país la supervivencia de grupos migrantes con una "conciencia de pertenencia étnica" y cierta "lealtad tribal", a pesar de que los rasgos culturales "tribales" se habían diluido en la homogeneidad cultural de la sociedad receptora ${ }^{44}$. Sobre la base de las diferentes propuestas hechas a partir del reconocimiento del pluralismo cultural y de los estudios que defienden un resurgimiento étnico en la tercera generación, Cecchi acomete una revisión crítica de las teorías que postulan el surgimiento de una "conciencia de pertenencia étnica" o 
"identificación étnica" en los nietos de inmigrantes, sostenida en estos términos por NAHIRNY y FISHMAN ${ }^{45}$.

La hipótesis generacional aplicada al fenómeno de la identificación étnica arranca del famoso postulado de Marcus Lee HANSEN (norteamericano de origen escandinavo) ${ }^{46}$, plasmado en la célebre frase: "Lo que los hijos quisieron olvidar, los nietos desean recordar" ${ }^{47}$, enunciado que desató una auténtica ola de estudios acerca de la identidad étnica en las sucesivas generaciones de migrantes, de cara a reafirmar o rebatir los principios hansenianos.

En los años 1990, nuevos estudios referidos a la etnicidad arrojaron otras hipótesis y nuevas lecturas de viejas teorías, como es el caso de la obra de Kivisto y Blanck ${ }^{48}$ subjetivo de la resurgimiento de la etnicidad en el aprticular contexto de la sociedad receptora (véase la reseña de $\mathrm{M}$. BJERG en Estudios Migratorios Latinoamericanos, $\mathrm{n}^{\circ}$ 18, CEMLA, Buenos Aires, agosto 1991, pp. 255-257). en relación a la hipótesis generacional de Hansen, y los trabajos que han enfatizado sobre el carácter dinámico de la etnicidad, cuyas reelaboraciones están condicionadas a la evolución interna del grupo migrante y a las "negociaciones" practicadas no sólo en su seno sino también con la sociedad receptora. Dentro de esta línea cabe destacar el estudio de K. CONZEN ${ }^{49}$, referido también al ámbito americano, en el que se pone el acento en el dinámico proceso de interacciones entre los diferentes grupos étnicos y la sociedad de acogida, cuyos parámetros de asimilación ofrecen un contexto cambiante a lo largo del tiempo, condicionando el proceso de adaptación de los migrantes.

No se trataba en mi caso de adscribirme a ciegas a los postulados hansenianos por así convenir a mis "sentimientos étnicos", sino de discernir los alcances del proceso de revalorización étnica en la tercera generación, definiendo sus matices particulares e intentando, en una etapa posterior, un estudio comparativo con los descendientes de otros grupos migratorios. Respecto a esa recuperación de la etnicidad en la tercera generación, CECCHI (1967) sostiene, con razón, que no cabe hablar de una herencia étnica en los nietos (en sentido cultural, no biológico) y menos aún ponerlos en la alternativa de negar o "abrazar" la etnicidad de origen, ya que ésta forma parte de una experiencia ajena, con la que es imposible identificarse. Por lo demás, una rígida perspectiva generacional es limitante y puede conducir a engaño, ya que en el seno de una familia de un determinado grupo inmigrante puede haber diferentes "velocidades" -en el proceso de adaptación- con relación a otras del mismo origen, rasgo que por cierto he podido constatar en las segundas generaciones de mi familia.

En tanto que yo misma me sentía protagonista de un fenómeno de revalorización de la herencia étnica, me decidí por el estudio de este aspecto en la tercera generación de inmigrantes sirio libaneses en Tucumán, a fin de constatar la veracidad de esa recuperación de la herencia 
cultural de acuerdo a los principios de Hansen y de las diferentes teorías que con matices se sitúan en esta línea.

En vísperas de mi viaje a Argentina a fines de 1993, elaboré un proyecto para el estudio de la conciencia étnica en los nietos de inmigrantes sirios y libaneses en Tucumán, planes que por diversos motivos no llegaron a concretarse en su totalidad, pues tanto en Argentina como en el posterior regreso a España a fines de 1994, las exigencias laborales me llevaron por otras sendas ocupacionales y temáticas. En el plan de trabajo elaborado en 1993 contemplaba el estudio de los tres grupos mayoritarios definidos en Tucumán conforme a sus creencias religiosas: maronitas, ortodoxos y musulmanes ${ }^{50}$, cuyas respectivas asociaciones étnicas eran muy conocidas en Tucumán. Con respecto al asociacionismo ${ }^{51}$, así como a otras cuestiones relacionadas con la comunidad árabe en Argentina y específicamente en Tucumán, contaba, por razones obvias, con un conocimiento de "primera mano" -por mi condición de descendiente de sirios-, muchas veces confirmado mediante la lectura de las fuentes bibliográficas ${ }^{52}$.

La metodología a aplicar en el trabajo se fundamentaba sobre todo en el estudio de las diversas oleadas migratorias ${ }^{53}$ y de las asociaciones étnicas correspondientes a los grupos mayoritarios dentro del conjunto de inmigrantes árabes, como así también el análisis de sus órganos de difusión, ya que el discurso de los mismos es revelador de la marcha del proceso de adaptación a la sociedad receptora. En el material consultado perteneciente a estas asociaciones, como las actas de la Sociedad Sirio Libanesa de Tucumán, llamaba la atención su proclamación de argentinidad en ocasión de festejos patrióticos, postura que bien podría verse como una estrategia para afianzarse como grupo étnico frente al país receptor.

La historia oral ocupaba un papel predominante para el tratamiento no sólo de los temas antes señalados sino también para el análisis del fenómeno de la identidad étnica en los nietos de inmigrantes sirios y libaneses en Argentina. Para ello se preveían entrevistas a miembros de la tercera generación, recurriendo a las personas relacionadas con las tres instituciones representativas de los tres grupos religiosos en Tucumán: Sociedad Sirio Libanesa (principalmente cristianos ortodoxos), Casa Libanesa (maronitas) y Asociación Panislámica (musulmanes). En lo que respecta al recurso de la historia oral ${ }^{54}$, son conocidas las dificultades con que se topa el investigador para acceder a los informantes idóneos, dada la resistencia de ciertos grupos, aunque yo contaba -en mi condición de miembro de la colectividad- con la ventaja no sólo del conocimiento de familias árabes en mi provincia, sino también en otras zonas del noroeste argentino. 


\section{CUESTIONES DE IDENTIDAD. LAS DIFERENCIAS GENERACIONALES}

Nací justamente cuando mediaba el siglo, una fecha que los estudiosos han señalado como la conclusión del proceso de adaptación de los inmigrantes árabes. Con anterioridad he marcado algunas diferencias entre mi familia materna y paterna con respecto al proceso de aculturación, aunque en general mis abuelos, como la generalidad de los árabes en Argentina, mostraron una gran flexibilidad a la hora de acomodarse al nuevo contexto ${ }^{55}$.

Por lo que se refiere a mi "sensibilidad étnica"56 en tanto nieta de inmigrantes, podría adelantar los resultados de algunas reflexiones aun cuando la investigación está sólo en ciernes. En primer lugar, como investigadora, puedo afirmar que al igual que sucede con cualquier objeto de estudio, también llegué a enamorarme del tema, lo que posiblemente podría haber alimentado la corriente de simpatía hacia la etnicidad de origen. Ese reclamo de lo étnico también deriva del hecho de haberme "solidarizado" con la experiencia migratoria de mis abuelos, dedicando una nueva mirada, más profunda, hacia tal fenómeno, pues yo lo había vivido en carne propia: la identificación con aquella experiencia se producía en cuanto yo repetía, con mi migración, el impulso que les llevó a dejar su tierra para instalarse en otra. Dentro de mi familia, no es casual que otra persona de la tercera generación que vivió -aunque por circunstancias políticas- lejos del país durante mucho tiempo, experimentase un similar interés por la etnicidad de origen.

La revalorización de lo étnico se operó pues en mi caso en unas circunstancias muy especiales: lejos de Argentina y ya radicada en España. $\mathrm{Y}$ es en este punto en el que debo hacer una salvedad: el proceso de recuperación de la etnicidad se vio favorecido por las valoraciones positivas de lo árabe que percibí especialmente a mi llegada, cuando viví en Andalucía. Por último, el rescate de ciertos elementos culturales de mis antepasados, parecía en cierto modo una reivindicación tardía a sus orígenes; con relación a mis abuelos, tenía la sensación de que salvo una que otra anécdota que guardaban, el envío de alguna carta a parientes o la visita ocasional de alguno de éstos, habían roto sus lazos con el país de origen. ¿Tal vez me tocaba a mí el recomponerlos, estudiando su experiencia migratoria? Se trataría, en este sentido, de un fenómeno de tipo intelectual, resultado de una inquietud que nace en individuos de la tercera generación pertenecientes a sectores sociales medios y altos, y desde una situación de completa asimilación, por lo que sería más acertado hablar de una "etnicidad adquirida"57.

Con relación a la situación vivida en Argentina como nieta de inmigrantes, puedo decir que yo misma experimentaba a veces mi propia alteridad, sobre todo en los aspectos lingüísticos y religiosos, aun a pesar 
de que no hablaba el árabe ni asistía -salvo en casos de fuerza mayor- al templo ortodoxo.

Es común observar hoy que casi ningún nieto de inmigrantes sirios o libaneses habla la lengua de sus abuelos. Este aspecto tuvo una gran incidencia en la vivencia de la etnicidad y en el proceso de adaptación al país de acogida, pudiendo observar tales efectos en mi propio caso (dado que sólo hablaba el árabe mi padre), e incluso la fuerza de la figura materna -mucho más si ostenta una conciencia étnica marcada- en la preservación del idioma; es así que primos hermanos por la vía paterna (hijos de hermanas de mi padre) hablaban el árabe o "lo entendían", ;o cual parecía una consecuencia lógica del mayor apego a lo étnico transmitido por sus madres en el seno de una familia árabe "tradicional".

No obstante, en el plano de las creencias, mi padre no demostró ưna rigidez en lo que se refiere a las prácticas religiosas, como así tampoco mis abuelos; por el contrario, una nieta de musulmanes- entre los cuales el culto se desarrolló en el ámbito doméstico hasta que se fundaron las mezquitas ${ }^{58}$, contaba que su hermano varón había sido preparado para ejercer la dirección de los oficios religiosos en una comunidad del interior de la provincia de Tucumán ${ }^{59}$. En lo que a mí respecta, cursé parte de la escuela primaria y la totalidad de la secundaria en un colegio católico -siendo ésta por ende la religión que practicaba-, lo que me generaba ciertas "incomodidades" a la hora de asistir a la iglesia ortodoxa en Tucumán, en ocasión de los funerales de parientes. El templo me resultaba extraño y además se oficiaba en árabe, experimentando la sensación de que cometía una "traición" a mis prácticas, hasta el punto que me sentí en la obligación de comunicar estos hechos a la monja que impartía aquella asignatura en mi colegio. Mayor "herejía" me parecía el que los curas fueran casados; este aspecto es destacado en el estudio de $\mathrm{Akmir}^{60}$, donde uno de sus informantes, refiriéndose a décadas anteriores, recuerda el recelo y extrañeza que causó en un principio la inexistencia del celibato sacerdotal entre los ortodoxos. Tanto han cambiado los tiempos que hace unos años pude ver en Tucumán cómo la feligresía católica asistía en masa a los oficios ortodoxos; incluso, desbordando las naves del templo, se aglomeraba en el atrio y hasta en la acera.

\section{CONCLUSIÓN}

Además de unos rasgos físicos particulares ${ }^{61}$ que denotan el origen racial, existe entre los descendientes de un determinado grupo étnico cierta esencia, aquello que una nieta de inmigrantes sirios procedente de Bahía (Brasil), definía textualmente como la "memoria celular"62 -memoria genética-, conforme a la cual se reproducirían de una generación a otra ciertas conductas arcanas. Con frecuencia me ha dado por pensar que en mi familia, uno de entre los hermanos, acabaría por atender al llamado de la 
sangre y obrar conforme a ese impulso errante que mueve al hombre de su terruño para instalarse en otras latitudes.

Lo árabe constituye sin duda un componente de mi identidad, aunque de un modo que resulta complejo definir, en tanto que he nacido y me he criado conforme a los patrones culturales del mundo occidental. Además de no hablar la lengua de mis abuelos, tampoco ellos me impusieron las pautas culturales que traían de sus aldeas de origen -muchas de las cuales siguen aun vigentes, conforme al testimonio de quienes las visitaron-. Sin embargo, comparto en gran medida el sentimiento que hace unos meses me expresara una persona de origen árabe, la menor de siete hermanos, perteneciente a la segunda generación de inmigrantes sirios en Argentina, con respecto a la etnicidad de origen: el viaje a la tierra de sus padres tenía una importancia vital, convencida como estaba que era allí donde "encontraría su otra mitad"63.

En definitiva, y parafraseando al escritor Mario Benedetti que habló de la "suma de nostalgias" para el que se exilia, creo que se es una "suma" de identificaciones (o lealtades), ya que a lo largo de nuestra trayectoria vital reinventamos continuamente la identidad, conforme a las interacciones que tienen lugar en la sociedad en la que estamos insertos. Por lo demás, corrigiendo aquella primera y desalentadora sensación de desarraigo que sufrí en mi retorno transitorio a Argentina, puedo ahora decir que soy poseedora de una suma de arraigos: pequeñas raicillas que han quedado clavadas en los sitios en los que repartí mi vida hasta ahora.

\section{NOTAS:}

1 En SAIGNES, Thierry, "América y nosotros: ensayo de ego-historia", Visión de los Otros y visión de sí mismos (F. del Pino y C. Lázaro, coord.), traducido por F. del Pino y B. Vitar, Biblioteca de Historia de América 12, Consejo Superior de Investigaciones Científicas, Madrid, 1995 , p. 36.

2 Dentro de la bibliografía referida al tema desarrollado en estas páginas citamos un artículo de Camillo CECCHI, "L' 'identificazione etnica' dei figli degli emigrati", en Studi Emigrazione, año IV, n 9, junio 1967, al final del cual se inserta una breve reseña del autor, escrita por otro estudioso brasileño, M. Diégues Jr. Tras destacar en estas notas los estudios de C. Cecchi sobre los migrantes italianos en Brasil desde su condición de inmigrante del mismo origen, Diégues expresa que "le 'storie di vita' sono senza dubbio le migliori fonti per lo studio degli atteggiamenti, delle reazioni, delle crisi di situazione dell'immigrato a contatto con la nuova cultura" (Manuel DIÉGUES JR., "Estudo das 
Relaçoes étnicas no Brasil", en Sociologia, vol. XVI, n², Sao Paulo, 1954, p. 33).

3 Incluso, entre los miembros de la tercera generación de inmigrantes se hallaba firmemente asentada la idea de que el arraigo a la sociedad argentina era absoluto.

4 En este punto recurro al estudio de León GRINBERG y Rebeca GRINBERG, Psicoanálisis de la migración y del exilio, Madrid, Alianza, 1984, en el que se analizan desde este particular enfoque los efectos traumáticos del hecho migratorio en los inmigrantes $y_{\text {, sus }}$ descendientes. Es de interés, para el estudio de la identidad étnica, el concepto de "duelos postergados" (p.24), asociado a las primeras generaciones, lo que explicaría desde una determinada perspectiva ese reclamo de la etnicidad vivido por los nietos de inmigrantes.

5 En este trabajo había tratado los procesos interculturales en una frontera hispano indígena -la zona de contacto entre la vieja gobernación del Tucumán y el Chaco indígena-, lo que acrecentó mi interés por el estudio del fenómeno de la identidad étnica en el proceso de inserción de las comunidades indígenas en la sociedad colonial.

6 De vuelta a mi país de origen pensaba concursar el ingreso a la carrera de investigador en el Consejo Nacional de Investigaciones Científicas y Técnicas, presentando como proyecto el estudio de alguna faceta de la inmigración de sirios y

7 También este país me interesaba, puesto que en la ciudad de San Pablo residen parientes de mi abuela materna.

8" GRINBERG y GRINBERG, ob. cit., hablan acertadamente de la "fantasía del retorno" (pp. 214-215).

9 GRINBERG y GRINBERG, ob. cit., p. 220. En esa vuelta, al llegar a Buenos Aires, experimenté con inquietud lo que a menudo me asaltaba en mis primeros tiempos en España: la sensación, como bien la describe Milan Kundera en relación a quien está en el extranjero, de transitar por "un espacio vacío en lo alto, encima de la tierra" (En $L a$ insoportable levedad del ser, pp. 81-82).

10 Citamos algunos, a título orientativo: A. SCHAMUN, La colectividad siria en la República Argentina, Santa Fe, 1910; L. A. BERTONI, "Los turcos en Argentina", ponencia presentada en las Primeras Jornadas Internacionales sobre Migraciones en América, Buenos Aires, 1983; Jorge O. BESTENE, "La inmigración sirio-libanesa en Argentina. Una aproximación", en Estudios Migratorios Latinoamericanos, $\mathrm{n}^{\circ}$ 9, 1988 y A. AKMIR, $L a$ 
11 Para una perspectiva regional -noroeste de Argentina- y de la migración árabe a otras provincias de esta zona, v. Gladys JOZAMI, "Aspectos demográficos y comportamiento espacial de los árabes en el NOA", en Estudios Migratorios Latinoamericanos, año 2, n 5 , Buenos Aires, 1987, pp. 57-90 y Alberto TASSO, "Migración e identidad social. Una comunidad de inmigrantes en Santiago del Estero", en Estudios Migratorios Latinoamericanos, $\mathrm{n}^{\circ}$ 6-7, Bs. As., 1987, pp. 321-336. Para Tucumán, se cuenta con dos trabajos específicos: M.A. SALEH DE CANUTO y S. BUDEGUER, El aporte de los sirios y libaneses a Tucumán, S.M. de Tucumán, 1979; M.E. VELA y R. CAIMI, "The Arabs in Tucuman", en L.M.Montiel (comp.), Asiatic Migrations in Latin America, México, 1981.

12 Véase, por citar sólo algunos ejemplos, el clásico estudio de S. ABOU, Liban deraciné. Inmigrés dans l'autre Amérique, París, 1974; O. TRUZZI, De mascates a doutores: sirios y libaneses en San Pablo, Sumaré, Sao Paulo, Brasil, 1992; A. SAMEER y A. NABEEL, The Arabs in the New World, Wayne State University, 1983 y L. CHUAQUI, Migración siriolibanesa en Chile, Sgo. de Chile, 1982.

13 Hay también en esto una razón numérica de peso, ya que la masa migratoria que ingresó a Argentina estuvo compuesta mayoritariamente por españoles e italianos.

14 Véase J. BESTENE, "Dos imágenes del inmigrante árabe: Juan A. Alsina y Santiago M. Peralta", en Estudios Migratorios Latinoamericanos, $\mathrm{n}^{\circ} 36$ (agosto 1997).

15 En total, el número de inmigrantes llegados entre 1890 y 1950 fue de 150.000 personas, según los datos de BESTENE (1997), ob. cit., p. 283.

16 En una encuesta realizada en 1992 entre 300 personas en Buenos Aires y publicada en el diario Clarín de 12 de abril de 1992, un $51 \%$ se inclinaba por la inmigración procedente de Europa del Este, un 26,7\% por la de países de Iberoamérica y un $16 \%$ por la asiática.

17 Véase BESTENE (1997).

18 Datos proporcionados por J.J.M., nieto de libaneses por línea materna, en una entrevista realizada en abril de 1994.

19 Entrevista a E.Ch. realizada en febrero de 1994. La expresión "timbero" alude a cierta afición por los juegos de cartas con que los socios amenizaban sus citas cotidianas en la Sociedad Sirio Libanesa de Tucumán. 
20 Para este tema véase lo estudiado por Fernando DEVOTO para el caso italiano: "Las cadenas migratorias italianas: algunas reflexiones a la luz del caso argentino", en Estudios Migratorios Latinoamericanos, $\mathrm{n}^{\circ} 8$, 1988.

21 JOZAMI (1987) y (1994).

22 En algunos casos, las futuras esposas venían solas desde Siria o Líbano a fin de contraer matrimonio en Argentina, con un inmigrante de ese origen (BESTENE, 1988, p. 251).

23 Sobre las diferencias religiosas entre los migrantes árabes véase Gladys JOZAMI, "Identidad religiosa e integración cultural en cristianos sirios y libaneses en Argentina, 1890-1990", en Estudios Migratorios Latinoamericanos, abril 1994, Bs. As., pp. 95-113.

24 Ibídem.

25. Ibídem, p. 110.

V. AKMIR (1991).

27 En castellano, jeque.

28 V. TASSO, ob. cit., p. 325; BESTENE (1988), p. 256-260 y JOZAMI (1987). El masivo vuelco hacia el comercio determinó que miembros destacados de la colectividad árabe buscaran inclinar a los recién llegados a la agricultura -no otra podía ser la demanda del país, que había conocido los beneficios de la "revolución cerealera" en las pampas-, a modo de conseguir una mejor acogida del grupo migrante por parte del país receptor (V. TASSO, ob. cit., p. 327).

Una frase que mostraba como ninguna la dificultad entre los hablantes árabes de pronunciar la "p".

V. TASSO, ob. cit.

31 Ocupación que por cierto también aparece en testimonios de otros migrantes en Santiago, recogidos por TASSO, ob. cit., p. 330.

BESTENE (1997), p. 293.

33 Cabe recordar que el quechua fue utilizado por los misioneros cristianos en la zona de influencia del antiguo imperio inca -caso del noroeste argentino-, como lingua franca para evangelizar a la población indígena. 
V. TASSO, ob. cit. p. 332.

35 Véase para este tema Estela BIONDI-ASSALI, "L'insertion de groupes de langue arabe dans la société argentine", en Revue Européene des Migrations Internationales, Vol. 7, $\mathrm{n}^{\circ} 2,1991$, pp. 139-151.

Entrevista a M.Y., realizada en Madrid en octubre de 1993.

37 Término muy utilizado en Argentina y probablemente acuñado entre los ganaderos propietarios de estancias -principalmente miembros de las élites nativas- para aludir al linaje de personas o grupos.

38 He aquí el típico caso de quienes eran "traídas" por el futuro esposo, ya asentado en la sociedad de acogida, cumpliendo la regla endogámica generalizada en el caso de los grupos de origen árabe.

39 Entrevista realizada a S.A. en mayo de 1994.

40 JOZAMI (1994), p. 108.

41 Institución que en principio nucleaba a los sirios y libaneses de religión ortodoxa, aunque en la práctica se caracterizó por la flexibilidad en las normas de admisión.

42 Véase el estudio comparativo de ambos países de Hebe CLEMENTI, El miedo a la inmigración, Buenos Aires, Leviatán, 1984.

43 Israel ZANGWILL, The Melting Pot, New York, Macmillan, 1909. Según sus postulados, las diferencias culturales de los diversos grupos étnicos se diluyen bajo la potencia homogeneizadora de los valores de la sociedad norteamericana.

44 CECHI, ob. cit., p. 209. Se exponen en este artículo de forma suscinta las diferentes teorías elaboradas en torno al problema de la identificación étnica de los inmigrantes en los Estados Unidos, una vez superado el concepto de amalgama étnica postulado por el "melting pot". Surgieron así una serie de estudios que caracterizaban a la sociedad americana como multicultural, al estar compuesta por una variada gama de grupos étnicos con sus particularidades culturales, ensayos todos que pueden agruparse en la línea interpretativa definida como pluralismo cultural, situada en el extremo opuesto al crisol de razas.

45 Vladimir NAHIRNY y Joshua A. FISHMAN, "American Immigrant Groups: Ethnic Identification and the Problem of Generations", en The Sociological Review, feb. 1958. Ambos autores sostienen que si bien la 
tercera generación se encuentra completamente asimilada y no recibió de los padres herencia cultural ninguna, se percibe en ella el resurgimiento del interés por la etnicidad de origen (véase $\mathrm{CECCHI}$, ob. cit., p. 212). Proceedings of the Marcus Lee Hansen Immigration Conference, Danes Worlwide Archives, Aalborg, Dinamarca, 1993.

47 En 1938, Hansen delimitó en cada generación un tipo de comportamiento diferente en lo que respecta a la vivencia de la etnicidad en el marco del país de acogida; así, la primera generación permanecería adherida a su tradición y costumbres y la segunda experimentaría una ambivalencia al sufrir los condicionamientos de dos sistemas de valores diferentes, produciéndose en la tercera el fenómeno de la revalorización de lo étnico (véase la reseña de $\mathbf{M}$. BJERG en Estudios Migratorios Latinoamericanos, $\mathrm{n}^{\circ}$ 24, Centro de Estudios Migratorios Latinoamericanos (CEMLA), Buenos Aires, agosto 1993, pp. 289-291).

Peter. KIVISTO y Dag BLANCK, American immigrant and their generations. Studies and commentaries of the Hansen thesis after fifty years, University of Illinois Press (Urbana) 1990. Ambos señalan' el valor de la tesis hanseniana en lo que respecta al enfoque generacional, pero teniendo en cuenta el carácter

49 Katlhleen N. CONZEN, "The invention of ethnicity: una lettura americana", en Altreitalie, $\mathrm{n}^{\circ} 3$, año 2, abril 1990, pp. 5-37. La autora sostiene que desde un punto de vista histórico, el concepto de "invención" permite comprender la aparición, la metamorfosis, la desaparición y la reaparición de la etnicidad" (p. 6).

50 Para estas cuestiones, véase JOZAMI (1994); Daniel SANTAMARÍA, Estado, Iglesia e Inmigración en la Argentina Moderna, en Estudios Migratorios Latinoamericanos, $\mathrm{n}^{\circ}$ 14, 1990; M. HILLAR, Historia de la Iglesia Católica Apostólica Ortodoxa de Antioquía en la República Argentina, Buenos Aires, 1928.

51 Este tema ha sido también tratado por J. BESTENE en "Formas de asociacionismo entre los sirio-libaneses en Buenos Aires, 1890-1950", en F. DEVOTO y E.J. MÍNGUEZ (comp.), Asociacionismo, Trabajo e Identidad Étnica. Los italianos en América Latina en una perspectiva comparada, Buenos Aires, 1992.

52 En general, los estudios referidos a los árabes en Argentina reflejaban en muchas ocasiones una historia vivida, por el hecho de pertenecer a dicha colectividad de migrantes en Tucumán y contar con una amplia 
parentela en Santiago del Estero y Salta (provincias todas pertenecientes a la región del Noroeste argentino).

53 Esta faceta es importante, en cuanto puede ser indicativa del nivel de arraigo de la familia en el país receptor.

54 La información de que dispongo para esbozar algunas interpretaciones respecto del fenómeno de la etnicidad en las distintas generaciones de inmigrantes árabes en Tucumán procede de testimonios obtenidos de informantes sin un cuestionario previo, abriendo las puertas a la espontaneidad de los narradores (personas de la segunda y tercera generación de inmigrantes).

55 Ello es tan cierto que en mi ámbito familiar, ha habido primos de mi padre que, al inmigrar, se registraron con nombres y apellidos castellanos, traducidos de sus correspondientes en árabe. A mi propio abuelo paterno lo conocí como "Amado" -un rasgo de criollismo inesperado-, siendo su verdadero nombre "Ahmed"; a su vez, mi abuelo materno, Meljim, era conocido en ciertas zonas de Santiago como "Pedro". Sin duda estos gestos implicaban de entrada una renuncia a ciertas particularidades étnicas, facilitando la adaptación al país receptor.

56 Término usado por NAHIRNY Y FISHMAN, ob. cit. (véase CECCHI, 1967).

57 Véase CECCHI, ob. cit., pp. 221-224.

58 En Argentina las mezquitas no se establecieron hasta los años '80.

$59 \quad$ Entrevista a A.L.Ch. en enero de 1996.

60 AKMIR, ob. cit.

61 En Argentina, era frecuente que la gente detectara sin tardanza mis rasgos de "paisana" (que era como se denominaba coloquialmente a las gentes de origen "turco").

62 Entrevista realizada a R.N. en Madrid (octubre de 1993).

63 Entrevista realizada a N.J.M. en agosto de 1998. 